\title{
Correction to: Determining soil quality in urban agricultural regions by soil enzyme-based index
}

\author{
Avanthi Deshani Igalavithana - Muhammad Farooq • Kye-Hoon Kim • \\ Young-Han Lee · Muhammad Farooq Qayyum • Mohammad I. Al-Wabel • \\ Sang Soo Lee $\cdot$ Yong Sik Ok
}

Published online: 4 January 2018

(C) Springer Science+Business Media B.V., part of Springer Nature 2017

Correction to: Environ Geochem Health

(2017) 39:1531-1544

https://doi.org/10.1007/s10653-017-9998-2

Unfortunately, in the original publication of the article, Prof. Yong Sik Ok's affiliation was incorrectly published. The author's affiliation is as follows.

The original article can be found online at https:// doi.org/10.1007/s10653-017-9998-2.

A. D. Igalavithana $\cdot$ S. S. Lee · Y. S. Ok $(\varangle)$

Korea Biochar Research Center and School of Natural Resources and Environmental Science, Kangwon National University, Chuncheon 24341, Korea

e-mail: soilok@kangwon.ac.kr

M. Farooq

Department of Agronomy, University of Agriculture,

Faisalabad 38040, Pakistan

\section{Farooq}

The UWA Institute of Agriculture, The University of

Western Australia, Perth, WA 6001, Australia

\section{K.-H. Kim}

Department of Environmental Horticulture, University of Seoul, Seoul 08826, Korea

Y.-H. Lee

Division of Plant Environmental Research,

Gyeogsangnam-do Agricultural Research and Extension

Services, Jinju 52773, Korea
1. Kangwon National University, Chuncheon 24341, Republic of Korea

2. O-Jeong Eco-Resilience Institute (OJERI), Division of Environmental Science and Ecological Engineering, Korea University, Seoul, Republic of Korea

\section{F. Qayyum}

Department of Soil Science, Faculty of Agricultural Science and Technology, Bahauddin Zakariya University, Multan, Pakistan

M. I. Al-Wabel

Soil Sciences Department, College of Food and Agricultural Sciences, King Saud University, P.O. Box 2460, Riyadh 11451, Saudi Arabia

Y. S. Ok

O-Jeong Eco-Resilience Institute (OJERI), Division of Environmental Science and Ecological Engineering, Korea University, Seoul, Republic of Korea e-mail: yongsikok@korea.ac.kr 